\title{
Preparation of $\alpha$-nickel hydroxide/carbon composite by the liquid phase deposition method
}

\author{
Alexis Bienvenu BÉLÉKÉ, Akinobu HOSOKAWA, Minoru MIZUHATA ${ }^{\dagger}$ and Shigehito DEKI \\ Department of Chemical Science and Engineering, Graduate School of Engineering, Kobe University, \\ 1-1, Rokko, Nada, Kobe 657-8501
}

High purity $\alpha$-nickel hydroxide/carbon composite has been synthesized by the liquid phase deposition (LPD) method. The purity of the as-prepared samples was confirmed by X-ray photon electron (XPS) survey spectra, which showed no other peak than that of the core levels Ni 2p, O 1s, C1s, Ni 3s and Ni 3p involved in the process. Scanning electron microscope (SEM) images showed carbon particles randomly embedded within the $\mathrm{Ni}(\mathrm{OH})_{2}$ network. The amount of deposited nickel hydroxide can be controlled by the ratio between carbon and the quantity of the treatment solution, and the reaction time.

(02009 The Ceramic Society of Japan. All rights reserved.

Key-words: Liquid phase deposition, Alpha-nickel hydroixde, Layered double hydroixde, Nickel metal hydride battery, Metal-fluoro complex

[Received November 17, 2008; Accepted January 15, 2009]

\section{Introduction}

Nickel hydroxide is widely used as a positive electrode active material in commercial nickel-based secondary batteries. ${ }^{1)}$ It possesses two phases in its reduced states known as $\alpha-\mathrm{Ni}(\mathrm{OH})_{2}$ and $\beta$ - $\mathrm{Ni}(\mathrm{OH})_{2}$, which transform to $\gamma-\mathrm{NiOOH}$ and $\beta-\mathrm{NiOOH}$, respectively, during charging. ${ }^{2}$ In most cases, the active material of the positive electrode belongs to the $\beta$-form. It is generally accepted that $\alpha-\mathrm{Ni}(\mathrm{OH})_{2}$ exhibits superior electrochemical properties compared to the $\beta$-form. ${ }^{3)}$ However, $\alpha-\mathrm{Ni}(\mathrm{OH})_{2}$ is labile and it rapidly converts to $\beta-\mathrm{Ni}(\mathrm{OH})_{2}$ during synthesis or in the presence of a strong alkaline solution. ${ }^{4)}$ While significant progress has been made regarding the stabilization of $\alpha$-phase in a strong alkaline medium by the insertion of metal additives within the lattice of $\mathrm{Ni}(\mathrm{OH})_{2}$, less attention has been devoted to nickel hydroxide composite materials from the view point of improving the electronic conductivity of the positive electrode. The addition of metal ions such as cobalt additives $\left(\mathrm{CoO}, \mathrm{Co}(\mathrm{OH})_{2}\right.$, etc. $)$ in the form of $\mathrm{CoOOH}$ conductive film on the spherical $\mathrm{Ni}(\mathrm{OH})_{2}$ by physical mixture, or its insertion in the lattice of $\mathrm{Ni}(\mathrm{OH})_{2}$ by chemical co-precipitation have proven to improve the discharge capacity rather than the electronic conductivity. ${ }^{5)-10)}$ The use of a conductive agent such as carbon as part of active materials for the positive electrode is regarded to be beneficial in the terms of enhancing the conductivity of electrochemical devices due to its highly accessible surface area, good electrical conductivity, chemical stability and mechanical strength. ${ }^{11)-14)}$ However, the commonly used approach which consists of the physical mixture of active material and carbon has some shortcomings in the terms of: (i) decreasing the load of $\mathrm{Ni}(\mathrm{OH})_{2}$ active material due to carbon low density and high surface area and, (ii) low utilization of efficiency of carbon black because of less contact between the conductor and active material. It is therefore desirable to explore alternative approaches for mixing. In this scope, Zhang et al. have recently reported on the high-rate discharge properties of $\beta$ -

\footnotetext{
Corresponding author: M. Mizuhata; E-mail: mizuhata @kobe-u. ac.jp
}

nickel hydroxide/carbon composite prepared by co-precipitation method. The authors found that the carbon black distributed in the $\beta-\mathrm{Ni}(\mathrm{OH})_{2} / \mathrm{C}$ material reduces the inner resistance of $\mathrm{Ni}(\mathrm{OH})_{2}$ particles. ${ }^{15)}$

In this study, we propose a very simple and convenient route to the synthesis of $\alpha$-nickel hydroxide/carbon composite by the liquid phase deposition (LPD) method. While efforts towards it stabilization in alkali media and electrochemical properties are still under investigation, we expect that such type of material would be suitable for applications.

\section{Experimental}

The Ni parent solution was prepared according to the procedure described in our previous work. ${ }^{16)}$ The carbon oxidative pretreatment was carried out as follows. $2.0 \mathrm{~g}$ of carbon black (Vulcan XC-72R, specific surface area: $255.8 \mathrm{~m}^{2} \mathrm{~g}^{-1}$ ) were first loaded in a bottomed flask set under refrigerant. Then $15.986 \mathrm{~g}$ of $\mathrm{KMnO}_{4}$ were dissolved into $200 \mathrm{ml}$ ion exchange water (IEW) by hot stirring for few minutes, and loaded into a $500 \mathrm{ml}$ mesh cylinder. Next, $132 \mathrm{ml}$ of the $4 \mathrm{M} \mathrm{HNO}_{3}$ solution was added on the $\mathrm{KMnO}_{4}$ solution. The amount of the mixture was adjusted with IEW to make $400 \mathrm{ml}$ solution, which was loaded in the bottomed flask containing carbon black. The system was mixed by stirring at $70^{\circ} \mathrm{C}$ for $4 \mathrm{~h}$ under refrigerant, filtrated and washed with hot water three times. The filtrate was again shacked into $400 \mathrm{ml}$ of $2 \mathrm{M} \mathrm{HCl}$ for $17 \mathrm{~h}$ at an ambient temperature, washed with hot IEW twice and dried at $110^{\circ} \mathrm{C}$ for $8 \mathrm{~h}$.

$\alpha-\mathrm{Ni}(\mathrm{OH})_{2} / \mathrm{C}$ composite was obtained as follows: a proper amount of oxidized carbon was loaded in a plastic bottle and therein; the reaction solution (consisting of $12.5 \mathrm{mmol} \mathrm{dm}^{-3}$ of $\mathrm{Ni}$ parent solution, $0.1 \mathrm{~mol} \mathrm{dm}^{-3}$ of $\mathrm{H}_{3} \mathrm{BO}_{3}$ and IEW carefully mixed in a volumetric mesh flask) was poured on. The initial concentrations of the $\mathrm{Ni}$ parent solution and $\mathrm{H}_{3} \mathrm{BO}_{3}$ were 30 mmol dm${ }^{-3}$ and $0.5 \mathrm{~mol} \mathrm{dm}$, respectively. The system was shacked ultrasonically for $10 \mathrm{~min}$ before diving into water bath to allow reaction at $50^{\circ} \mathrm{C}$ up to $48 \mathrm{~h}$. The sample was collected by suction filtration, washed repeatedly with hot IEW and dried at $60^{\circ} \mathrm{C}$ for $3 \mathrm{~h}$. 
For cyclic voltammetry measurements, the positive electrode was prepared as follows. $50 \mathrm{mg}$ of the composite (ca. $80 \%$ nickel hydroxide and ca. 20\% carbon) was mixed with $200 \mathrm{mg}$ of $20 \mathrm{~g} \mathrm{dm}^{-3}$ polyvinyl alcohol (PVA; M. W. = ca 500) as a binder to make a paste. The mixture was inserted into $1.5 \times 1.5 \mathrm{~cm}^{2}$ nickel foam, dried in the air at $120^{\circ} \mathrm{C}$ for $3 \mathrm{~h}$ and, then pressed under a pressure of $20 \mathrm{MPa}$ for $1 \mathrm{~min}$. The working electrode active surface area was $1 \times 1 \mathrm{~cm}^{2}$. Nickel foam $\left(1.5 \times 1.5 \mathrm{~cm}^{2}\right)$ was used as counter electrode whereas $6 \mathrm{M} \mathrm{KOH}$ solution served as an electrolyte. Measurements were conducted at a scan rate of $1 \mathrm{mV} \mathrm{s}^{-1}$ against $\mathrm{Ag} / \mathrm{AgCl}$ for 5 cycles.

\section{Results and discussion}

\subsection{Analysis of the composite}

Powder XRD patterns of $\alpha-\mathrm{Ni}(\mathrm{OH})_{2} / \mathrm{C}$ composite are shown in Fig. 1. All the diffraction peaks are similar to those reported for $\alpha$-nickel hydroxide thin film, ${ }^{16), 17)}$ and are consistent with that of $\alpha-\mathrm{Ni}(\mathrm{OH})_{2} \cdot 0.75 \mathrm{H}_{2} \mathrm{O}$, (JCPDS card No $\left.38-715\right),{ }^{18)}$ except for the first reflection. The high intensity of the (003) plane indicates that the obtained phase has a good crystallinity. The broadening of the (006) reflection plane is caused by its combination with the graphite peak, which indicates the presence of carbon. No other peak for impurities or $\beta$-phase could be detected.

XPS spectra survey of the composite is shown in Fig. 2. The two peaks at 873.2 and $855.6 \mathrm{eV}$ are assigned to Ni $2 \mathrm{p} 1 / 2$ and $\mathrm{Ni} 2 \mathrm{p} 3 / 2$ core level, respectively. O 1 s core level is located at $531.9 \mathrm{eV}$ while that of $\mathrm{C} 1 \mathrm{~s}$ appears at $285.2 \mathrm{eV}$. The last two peaks at 112.6 and $66.9 \mathrm{eV}$ belong to $\mathrm{Ni} 3 \mathrm{~s}$ and Ni 3p core level,

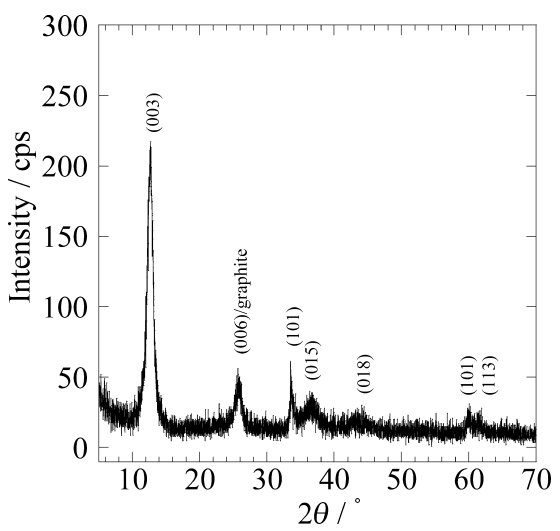

Fig. 1. Powder X-ray diffraction patterns of the as-deposited $\alpha$ $\mathrm{Ni}(\mathrm{OH})_{2} / \mathrm{C}$ composite.

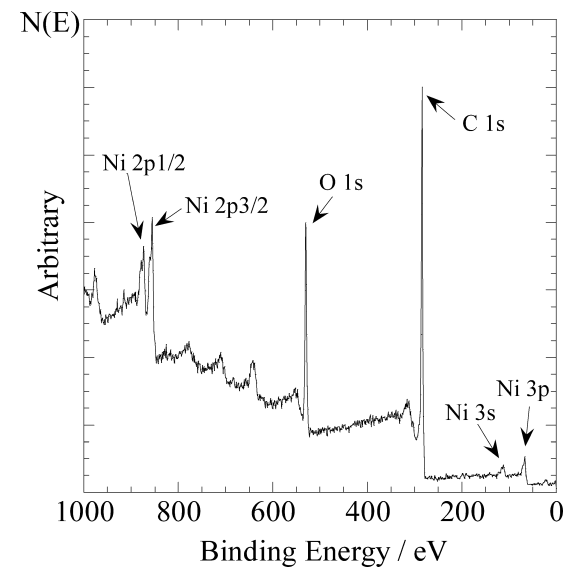

Fig. 2. XPS spectra survey of $\alpha-\mathrm{Ni}(\mathrm{OH})_{2} / \mathrm{C}$ composite. respectively. ${ }^{19)}$ No peak for impurity or other element is found in the XPS spectra, indicating the purity of the $\alpha$-phase $\mathrm{Ni}(\mathrm{OH})_{2} / \mathrm{C}$ composite synthesized under the current experimental conditions.

\subsection{Effects of composition and reaction time}

Figure 3 shows SEM images of the as-deposited $\alpha-\mathrm{Ni}(\mathrm{OH})_{2} / \mathrm{C}$ composite at two different carbon contents. In both cases, carbon particles can be easily distinguished from the $\alpha-\mathrm{Ni}(\mathrm{OH})_{2}$ network. However, in Fig. 3(a), which contains a high amount of carbon $\left(0.2 \mathrm{~g} \mathrm{l}^{-1}\right)$, the carbon particles appear as aggregates within the $\alpha-\mathrm{Ni}(\mathrm{OH})_{2}$ network whereas in Fig. 3(b) with a small amount of carbon $\left(0.13 \mathrm{~g} \mathrm{l}^{-1}\right)$, the feature exhibits abundant amount of nickel hydroxide. In other words, the amount of deposited $\mathrm{Ni}(\mathrm{OH})_{2}$ on carbon particles depends upon the amount of carbon (in gram) and quantity of reaction solution (in liter). The larger the solution content, the higher the amount of deposition, and the better distribution of carbon particles within the $\mathrm{Ni}(\mathrm{OH})_{2}$ network. Besides this composition factor, the reaction time plays a crucial role in controlling the amount of deposition. According to SEM images and XRD patterns (not shown), the deposition occurs after at least $6 \mathrm{~h}$ of reaction but with a low amount of $\mathrm{Ni}(\mathrm{OH})_{2}$. Increasing the reaction time from 12 to $48 \mathrm{~h}$ did not show any change in the sample morphology nor structure, but displays rather the increase in the intensity of the (003) reflection and the decrease of the graphite peak. These results indicate that the amount of deposition can be controlled by the initial concentrations and the reaction time.

\subsection{Cyclic voltammetry}

Figure 4 shows cyclic voltammetry of the electrochemical cell made using $\alpha-\mathrm{Ni}(\mathrm{OH})_{2} / \mathrm{C}$ composite as an active material of the
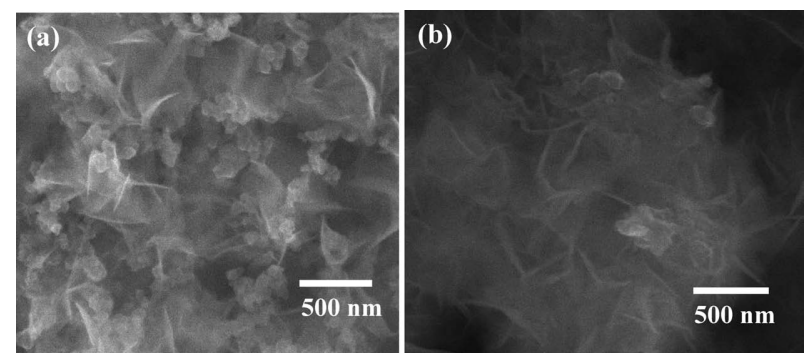

Fig. 3. SEM images of the as-deposited $\alpha-\mathrm{Ni}(\mathrm{OH})_{2} / \mathrm{C}$ composite at two different carbon contents: (a) $0.2 \mathrm{~g} \mathrm{l}^{-1}$, (b) $0.13 \mathrm{~g} \mathrm{l}^{-1}$.

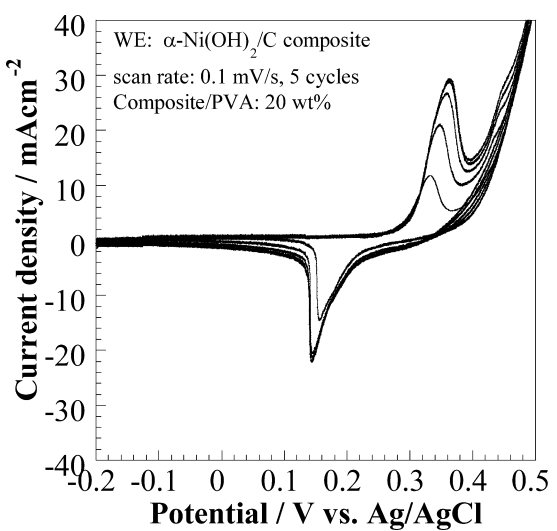

Fig. 4. Cyclic voltammograms of the cell made with $\alpha-\mathrm{Ni}(\mathrm{OH})_{2} / \mathrm{C}$ composite as working electrode. 
working electrode. The oxidation peak $\mathrm{E}_{\mathrm{a}}$ (which describes the cycling behavior at the anode) appears at ca. $370 \mathrm{mV}$ before the oxygen evolution, and shifts towards positive potentials with an increasing number of cycles. The intensity also increases in the same way until the 4th cycle, then, it becomes stable at the 5th cycle. The reduction peak $E_{\mathrm{c}}$, (showing the cycling behavior at the cathode) for the first cycle is located at $133 \mathrm{mV}$, and slightly shifts towards negative potentials. These peaks are assigned to the $\gamma-\mathrm{NiOOH} \rightarrow \alpha-\mathrm{Ni}(\mathrm{OH})_{2}$ process. The potential difference between $E_{\mathrm{a}}$ and $E_{\mathrm{c}}, \Delta E_{\mathrm{a}, \mathrm{c}}$, was used to estimate the reversibility of the electrode reaction. A value of $179 \mathrm{mV}$ was found for $\Delta E_{\mathrm{a}, \mathrm{c}}$, which is higher compared to the theoretical value of $158 \mathrm{mV}$, and implies somewhat a low reversibility. The large volume of the active material is suspected as a principal cause of this low reversibility. There may be an excess of composite loaded into the electrode active surface area, which could hinder the proton diffusion process. Another hypothesis is that the current scan rate of $1 \mathrm{mV} \mathrm{s}^{-1}$ could be too fast to detect the electrochemical response. It is well-known that the separation between redox peaks, $\Delta E_{\mathrm{a}, \mathrm{c}}$ is the combination of two main factors such as the ohmic drop and the energetics of the ion insertion-expulsion reaction, ${ }^{20,21)}$ the latter factor includes many parameters such as proton concentration, the electrolytic concentration and so on. On the other hand, the electrode can only intercalate or deintercalate the number of proton commensurate with the volume of the active material available. ${ }^{22)}$ It is therefore difficult at this stage to state on which of the two factors is responsible of this low reversibility. Efforts to improve the electrochemical properties are currently on process and this aspect will be elucidated subsequently.

\section{Conclusion}

$\alpha-\mathrm{Ni}(\mathrm{OH})_{2} / \mathrm{C}$ composite has been successfully prepared by the LPD method. The high intensity of the (003) reflection in the diffraction patterns indicate that the composite possesses a good crystallinity. No other peak of $\beta$-phase was detected. XPS survey spectra confirm the purity of the samples under current synthesis conditions. The amount of deposited nickel hydroxide can be controlled by the reaction conditions such as the composition ratio between the amount of carbon and the content of the treatment solution, and the reaction time. With further investigation, $\alpha-\mathrm{Ni}(\mathrm{OH})_{2} / \mathrm{C}$ composite is expected as a potential candidate of the positive electrode active materials for rechargeable nickelbased batteries.

Acknowledgment This study was carried out as the Energy and Environment Technologies Development Projects; "Development of an Electric Energy Storage System for Grid-connection with New Energy Resources" supported by Kawasaki Heavy Industries, Ltd. and New Energy and Industrial Technology Development Organization (NEDO). We would like to thank Professor Hiroshi Inoue and
Dr. Eiji Higuchi of Osaka Prefecture University for discussion about the evaluation test of the electrode.

\section{References}

1) N. Sac-Epée, M. R. Palacin, B. Beaudoin, A. Delahaye-Vidal, T. Jamin, Y. Chabre and J. M. Tarascon, J. Electrochem. Soc., 144, 3896-3907 (1997).

2) P. Olivia, J. Leonardi, D. Delmas, J. J. Braconnier, M. Figlarz, F. Fievret and A. de Guibert, J. Power Sources, 8, 229-255 (1982).

3) A. Delahaye-Vidal and M. Figlarz, J. Appl. Electrochem., 17, 589-599 (1987).

4) F. Portemer, A. Delahaye-Vidal and M. Figlarz, $J$. Electrochem. Soc., 139, 671-678 (1992).

5) A. Audemer, A. Delahaye, R. Farhi, N. Sac-Epée and J. M. Tarascon, J. Electrochem. Soc., 144, 2614-2620 (1997).

6) M. Oshitani, K. Takashima and S. Tsuji, J. Appl. Electrochem., 16, 403-412 (1986).

7) A. Cressent, V. Pralong, A. Audemer, J. B. Leriche, A. Delahaye-Vidal and J. M. Tarascon, Solid State Sciences, 3, 65-80 (2001)

8) J. H. Park, S. Kim, O. O. Park and J. M. Ko, Appl. Phys. A, 82, 593-597 (2006).

9) A. H. Zimmerman and P. K. Effa, J. Electrochem. Soc., 131 , 709-713 (1984).

10) D. A. Corrigan and R. M. Bendert, J. Electrochem. Soc., 136, 723-728 (1989).

11) J. Lv, J. P. Tu, W. K. Zhang, J. B. Wu, H. M. Wu and B. Zhang, J. Power Sources, 132, 282-287 (2004).

12) C. Delacourt, C. Wurm, L. Laffont, J.-B. Leriche and C. Masquelier, Solid State Ionic, 177, 333-341 (2006).

13) D. Aurbach, M. D. Levi, G. Salitra, N. Levy, E. Pollak and J. Muthu, J. Electrochem. Soc., 155, A745-A753 (2008).

14) C. H. Doh, C. W. Park, H. M. Shin, D. H. Kim, Y. D. Chung, S. I. Moon, B. S. Jin, H. S. Kim and A.Veluchamy, J. Power Sources, 179, 367-370 (2008).

15) W. K. Zhang, X. H. Xia, H. Huang, Y. P. Gan, J. B. Wu and J. P. Tu, J. Power Sources, 184, 646-651 (2008).

16) S. Deki, A. Hosokawa, A. B. Béléké and M. Mizuhata, Thin Films Solids, 517, 1446-1554 (2009).

17) P. Jeevanandam, Y. Koltypin and A. Gedanken, Nano Lett., 1, 263-266 (2001).

18) B. Post, "Power Diffraction File for Organic and Inorganic Substances, Inorganic Volume," W. F. McClune Managing Editor, No PD1S-22iRB, Pennsylvania (1980) p. 869.

19) C. D. Wagner, W. M. Riggs, L. E. Davis, J. F. Moulder and G. E. Muilenberg Editor, "Handbook of X-Ray Photoelectron Spectroscopy," Perkin-Eimer, December (1978) p. 80.

20) A. M. Bond, S. Fletcher and P. G. Symons, Analyst, 123, 1891-1904 (1998).

21) A. M. Bond, S. Fletcher, F. Marken, S. J. Shaw and P. G. Symons, J. Chem. Soc. Faraday Trans., 92, 3925-3933 (1996).

22) K. P. Ta and J. Newman, J. Electrochem. Soc., 146, 2769-2779 (1999). 